\title{
Electrophysiology of Sodium Receptors in Taste Cells
}

\author{
Albertino Bigiani \\ Dipartimento di Scienze Biomediche, Metaboliche e Neuroscienze, Università di Modena e Reggio Emilia, \\ Modena, Italy \\ Email: albertino.bigiani@unimore.it
}

Received 11 March 2016; accepted 26 June 2016; published 30 June 2016

Copyright (C) 2016 by author and Scientific Research Publishing Inc.

This work is licensed under the Creative Commons Attribution International License (CC BY).

http://creativecommons.org/licenses/by/4.0/

(c) (i) Open Access

\begin{abstract}
Sodium intake is important to maintain proper osmolarity and volume of extracellular fluid in vertebrates. The ability to find sources of sodium ions for managing electrolyte homeostasis relies on the activity of the taste system to sense salt. Several studies have been performed to understand the mechanisms underlying $\mathrm{Na}^{+}$reception in taste cells, the peripheral detectors for food chemicals. It is now generally accepted that $\mathrm{Na}^{+}$interacts with specific ion channels in taste cell membrane, called sodium receptors. As ion channels, these proteins mediate transmembrane ion fluxes (that is, electrical currents) during their operation. Thus, a lot of information on the functional properties of sodium receptors has been obtained by using electrophysiological techniques. Here, I review our current knowledge on the biophysical and physiological features of these receptors obtained by applying the patch-clamp recording techniques to single taste cells.
\end{abstract}

\section{Keywords}

Sodium Taste, Epithelial Sodium Channel, Patch-Clamp Recording

\section{Introduction}

Sodium ion represents the main cation of the extracellular fluid in vertebrate body. $\mathrm{Na}^{+}$has to be ingested with foodstuffs to balance its loss through, for example, urine and sweat. The ability to detect $\mathrm{Na}^{+}$sources is therefore essential for survival, and a specific taste sensitivity (called salty taste in humans) has evolved to ensure adequate sodium intake and homeostasis [1]-[4]. Sensing $\mathrm{Na}^{+}$by taste cells in the oral cavity relies on the activity of specific membrane proteins (sodium receptors) that work as ion channels [5]. Thus, research on mechanisms underlying $\mathrm{Na}^{+}$detection has been mainly accomplished by using electrophysiological techniques. In this paper, I will review our current understanding of the biophysical and functional properties of sodium receptors as de- 
duced by applying the technique of patch-clamp recording to single taste cells. A lot of studies on sodium reception have been also performed by recording the activity of fibers in taste nerves (chorda tympani and glossopharyngeal) while stimulating the tongue with salt solutions. However, I will not describe these experiments here because nerve recording techniques monitor the integrated, encoded output from taste buds, that is, downstream of the initial events of sodium detection and transduction. Extensive literature and nice reviews on this topic are already available [7]-[12].

\section{Taste Cells and Taste Receptors}

Taste cells are specialized epithelial cells clustered into ovoid structures, the taste buds [13] [14]. In mammals, taste buds are housed mainly in specific structures of the tongue mucosa called fungiform, foliate, and circumvallate papillae [14]. Taste cells are structurally and functionally polarized (Figure 1): the membrane that gets into contact with the saliva is called apical membrane and contains the molecular elements for the detection of food chemicals (taste receptors); the membrane beneath the intercellular junctions between adjacent cells is called basolateral membrane and expresses several types of proteins involved in signal transduction and transmission to nerve endings [5] [8] [15]. Thus, like hair cells in the inner ear and photoreceptors in the retina, taste cells work as an interface between external stimuli and afferent neurons conveying information to the brain. Unlike other sensory cells, however, taste cells exhibit two distinctive features, namely, they undergo continuous turnover as the surrounding epithelia [13], and they are endowed with voltage-gated ion channels underlying action potential firing [16]. Therefore, taste cells are epithelial cells with neuronal-like properties. As nicely pointed out by Avenet [17] "This duality, epithelia cell on one hand, nerve cell on the other, confers on these cells a unique combination of epithelial and nerve ion channels": the transduction mechanism for sodium ions represents indeed a paradigmatic example of such duality.

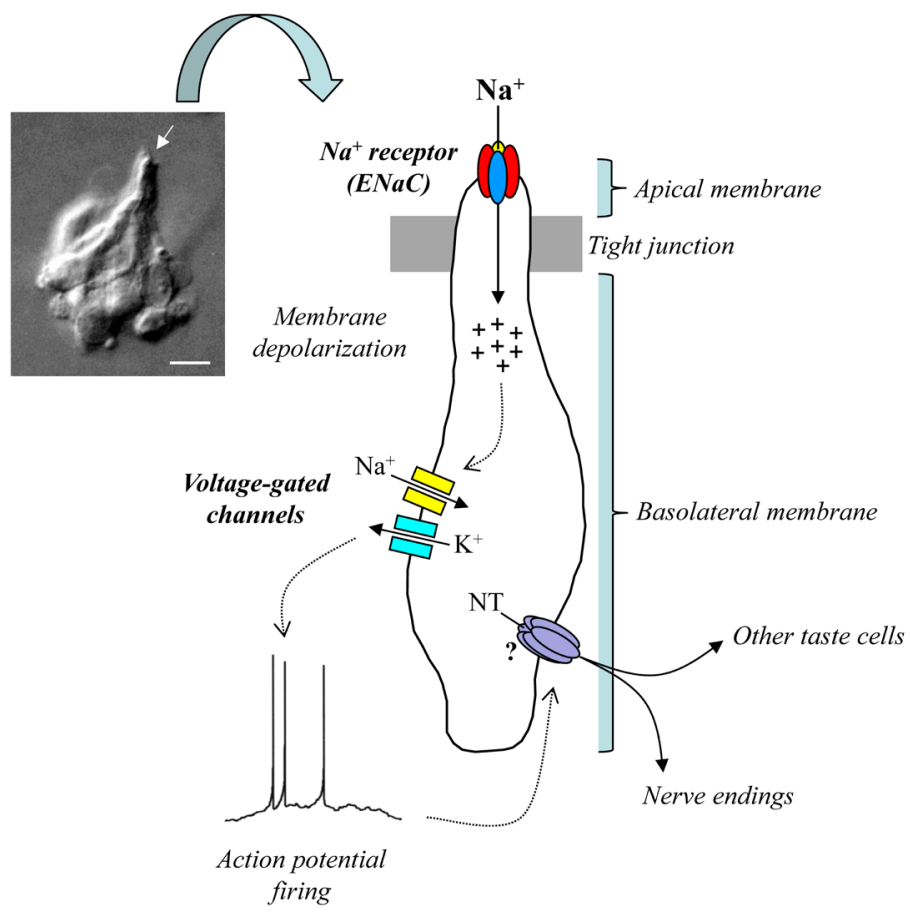

Figure 1. Hypothetical model of the transduction pathway for the detection of sodium ions $\left(\mathrm{Na}^{+}\right)$in taste cells. Apical ion channels (in this case, the epithelial sodium channel, ENaC) work as sodium receptors. When the $\mathrm{Na}^{+}$concentration in the saliva increases, $\mathrm{Na}^{+}$flows into the cell driven by its electrochemical gradient. This inward current leads to membrane depolarization, which in turn activates voltage-gated ion channels underlying action potential firing. Communication between sodium-chemosensitive cell and nerve endings or other adjacent taste cells could be mediated by neurotransmitter (NT) release through non-conventional synapses, although this is speculative at the moment (?). Inset: A taste bud isolated from rat fungiform papilla observed with differential interference contrast microscope. Arrow points to the apical end of taste cells. Scale bar: $5 \mu \mathrm{m}$. 
There are two main categories of taste receptors: G-protein coupled membrane receptors (GPCRs) that interact with organic substances and ion channels for inorganic ions [5] [18]-[23]. Substances that elicit sweet (e.g., sucrose in desserts), bitter (e.g., caffeine in coffee), and umami (e.g., glutamate in parmesan cheese) tastes in humans interact with specific GPCRs in the apical membrane (T1R1-3, T2Rs), which then trigger an intracellular enzymatic cascade leading to $\mathrm{Ca}^{2+}$ release from intracellular stores, opening of transient receptor potential M5 (TRPM5) channels, membrane depolarization, and action potential firing in the basolateral membrane [15] [21] [22]. Detection and transduction of acidic compounds (e.g., acetic acid in vinegar that elicits sour taste) involve different molecular pathways in which protons enter taste cells either through a proton-selective ion channel or by crossing directly the cell membrane as undissociated acid: the subsequent intracellular acidification is believed to cause membrane depolarization by shutting-down resting $\mathrm{K}^{+}$channels [15] [24].

As to sodium detection, recent data with genetically engineered mice support the notion that the epithelial sodium channel (ENaC) works as taste receptor [25] for the amiloride-sensitive (AS) component of the salt taste response [7] [9]-[11], so named for the inhibitory effect exerted by amiloride, a diuretic drug (see below). Other mechanisms have been proposed to explain the amiloride-insensitive ( $A I$ ) component of sodium taste, but at the moment the molecular candidates are elusive. The AS component is believed to be involved in taste recognition of $\mathrm{Na}^{+}$and to mediate the "saltiness", whereas the AI mechanism may represent an aversive pathway activated to avoid excessive ingestion of salt and inorganic electrolytes [2] [4] [7]-[10]. ENaCs are selective for $\mathrm{Na}^{+}$over other cations, such as $\mathrm{K}^{+}$, whereas channels underlying AI taste response may allow different cations to pass through (non-specific channels). The relative contribution of AS and AI components to sodium reception depends on the mammalian species and on the papillary localization of taste cells. In general, species with a low sodium diet, i.e. herbivores, and some omnivores, such as the rodents, utilize $\mathrm{ENaC}$ as a specific sodium receptor, whereas carnivores may utilize a more non-selective ion channel [8]-[10] [23] [26]. Functional ENaCs are usually located predominantly in taste cells of the anterior part of the tongue, namely at the level of fungiform papillae, whereas AI component prevails in the circumvallate papillae in the back of the tongue [27], although this pattern cannot be generalized [28]. Both AS and AI components have been described for sodium taste in humans [10] [29]-[31].

\section{Taste Transduction of Sodium Ions: an Electrophysiological Tale}

The current view of the mechanism underlying $\mathrm{Na}^{+}$taste reception can be summarized as follows (Figure 1): Taste cells sensitive to $\mathrm{Na}^{+}$possess specific ion channels in their apical, chemo-sensitive membrane. When $\mathrm{Na}^{+}$ concentration increases in the saliva due to release from foodstuffs, $\mathrm{Na}^{+}$enters into taste cells through apical channels driven by its electrochemical gradient. This flux is an electrical current that depolarizes cell membrane and eventually leads to action potential firing and signal transmission to nerve fibers [8] [18] [19]. The apical channels behave as sodium receptors, since they recognize $\mathrm{Na}^{+}$and allow it to get into taste cells.

The first indications that taste cells sense $\mathrm{Na}^{+}$through an electrogenic ion transport mechanism were provided by the seminal works of DeSimone and collaborators early in the 80'. By recording the electrical activity of rat taste nerves during stimulation of the tongue with salt solutions, they found that nerve response diminished in the presence of amiloride, which blocks the transport of several ions, including sodium [32]. The effect of amiloride on sodium taste was also observed in man [33]. With the advent of patch-clamp recording techniques [34], it has been possible to analyze in detail the sodium transport responsible for salt taste in single taste cells. By then, several studies have demonstrated that an amiloride-sensitive sodium channel, molecularly identified as epithelial sodium channel (ENaC), mediates the transmembrane current underlying the initial electrical events of the taste transduction for sodium, at least in part (see above). The contribution of $\mathrm{ENaC}$ to salt taste response varies significantly among mammalian species and even among different strains of a given animal [10] [23].

Patch-clamp technique has been a breakthrough in taste research. Mammalian taste cells are very tiny (cell body with a diameter $<10 \mu \mathrm{m}$ ) and early experiments with intracellular electrodes provided distorted information about their membrane electrophysiology. Intracellular recording is feasible and reliable in large cells, such as motoneurons and muscle fibres, since the electrical short-cut produced by membrane damage induced by microelectrode impalement is negligible compared to the ion flows through the whole intact membrane [35]. This reasoning led Stephen D. Roper to use the large taste cells of Necturus maculosus for intracellular recording: he was able to record the first action potentials in these sensory cells, indicating that they were electrically excitable [36]. His influential work and results were subsequently confirmed in the small taste cells of other vertebrates 
(such as, frog, mouse, and rat) thanks to the patch-clamp recording technique (e.g., frog [37]; mouse [38]; rat [39]).

\section{Epithelial Sodium Channel (ENaC)}

The epithelial sodium channel (ENaC) is a key membrane protein underlying absorption of $\mathrm{Na}^{+}$in many epithelia, such as those found in kidney, colon, and lung [40]. This channel differs both molecularly and functionally from the voltage-gated $\mathrm{Na}^{+}$channel [41] underlying action potential firing, whereas it shares primary structure homology with the acid-sensing ion channel (ASIC) expressed preferentially by neurons [42] but also found in taste cells [5]. The study of ENaC is tightly linked to the use of amiloride as pharmacological tool [43]. Amiloride affects several membrane transporters and ion channels; in the submicromolar concentration range, however, it is a specific reversible blocker of $\mathrm{ENaC}$ [8]. Thus, amiloride can be used to monitor the presence of functional ENaCs. Patrick Avenet and Bernd Lindemann [44] first recorded amiloride-sensitive sodium currents in frog taste cells. Subsequently, these currents were demonstrated also in taste cells from rodents (hamster [45]; mouse [46]; rat [27]). The majority of available data have been obtained by using the patch-clamp technique in the whole-cell, voltage-clamp configuration and its variations, such as the perforated-patch recording [47], but a few works were performed also on membrane patches excised from taste cells.

\subsection{Tissue Preparations for Patch-Clamp Recording}

Patch-clamp recording studies of ENaCs in taste cells have been accomplished by using mainly three different tissue preparations: isolated taste cells (frog [44] [48] [49]), isolated taste buds (hamster [28] [45]; mouse [50] [51]; rat [27] [52]-[56]), or single taste bud isolated with a piece of epithelium and arranged in such a way to keep apical and basolateral membranes separated (mouse [46] [57]-[62]; rat [63]). All these preparations have in common the requirement for enzymatic digestion to separate taste cell/tissue from surrounding epithelium/lamina propria of the tongue mucosa. To avoid enzymatic treatment, a method for maintaining taste buds in tissue slices was initially developed with Necturus tongue [64] [65]. However, with the exception of a later study on rat vallate papilla [66], no standard method has been developed to patch record taste cells maintained in tissue slices [67]-[69].

The main advantage of isolated single taste cells or taste buds is that they are easy to collect, and cell membrane is readily accessible for patch-clamp pipettes. However, there are two main problems when recording in whole-cell configuration. First, if amiloride is bath-applied, it is not possible to establish the membrane localization of functional ENaCs, and this has to be taken into account when interpreting the results [45] [52]. Note also that in isolated cells, apical membrane proteins may spread over the basolateral membrane due to disruption of intercellular junctions [44]. Second, both apical and basolateral membranes are exposed to the same extracellular solution, which does not reflect the physiological situation in situ. In particular, exposure of apical membrane to high- $\mathrm{Na}^{+}$concentration (as found in standard physiological saline, such as Tyrode's) may affect the functioning of ENaCs due to the phenomenon of sodium self-inhibition (see below). These drawbacks are overcome with taste buds maintained in peeled epithelial sheets: this preparation allows one to bathe apical and basolateral membranes with different solutions. As usual in experimental research, the choice of preparations depends on the information to be obtained. Isolated taste cells/buds are adequate to study the biophysical and pharmacological properties of ENaCs and how they are affected by different conditions (e.g., hormonal regulation [45] [51]; drug effects [56]). On the other hand, taste bud cells in epithelial sheets are more appropriate when studying channels in their actual membrane localization (e.g., [61] [62]. Indeed, this preparation has allowed demonstrating definitely the occurrence of functional ENaCs only in the apical membrane of taste cells [62].

Much of the initial patch-clamp work on taste ENaC was conducted on frog taste cells [44] [48] [70]. Unlike rodents (rat, mouse, hamster), which now represent the animal models widely used in taste research, the role of ENaCs in salt reception in frog is not yet fully understood, since these channels seem to be located in the basolateral membrane and not in the apical, chemo-sensitive tips of taste cells [71]. Nevertheless, the information gathered with frog taste cells, in terms of both experimental methodology and membrane biophysics, has been fundamental for the following research on rodents, and therefore it will be reviewed in this paper.

\subsection{Whole-Cell Recording}

$\mathrm{ENaC}$ is a constitutively active channel and contributes to the "leakage" ion flow across cell membrane in 
whole-cell voltage-clamp configuration (Figure 2; $I_{\text {leak }}$ ). This background current can be so large to obscure other membrane currents, such as the voltage-gated ones [44]. When holding the membrane potential at negative values, usually around $-80 \mathrm{mV}$, ion current through functional ENaCs appears as a stationary inward current (Figure 3; $I_{h}$ ). This stationary current is due to a continuous influx of $\mathrm{Na}^{+}$through open ENaCs since cells are submerged into an extracellular solution enriched of sodium ions (e.g., [27] [44] [45]). In these conditions, bath-application of amiloride induces a reduction in the stationary current that is called the response to amiloride (Figure 3; $I_{A m}$ ). Typically, the drop in membrane current is accompanied by a decrease in the noise level of the current trace (Figure 3), consistent with the closure of ENaCs [17] [48] [72], and by an increase in cell input resistance (e.g., [27] [45]), an indirect estimation of the membrane resistance. The detailed study of the response to amiloride has provided information on the biophysical and pharmacological properties of taste ENaCs. Note that the use of amiloride allows one to separate the contribution of ENaCs from other resting channels (e.g., leak $\mathrm{K}^{+}$channels [73] [74]) in making the leakage current.

Ion selectivity-Permeability ratio for $\mathrm{Na}^{+}$and $\mathrm{K}^{+}\left(\mathrm{P}_{\mathrm{Na}} / \mathrm{P}_{\mathrm{K}}\right)$ can be evaluated by measuring the response to amiloride at different membrane potentials and then by fitting the experimental data to the Goldman-HodgkinKatz equation for membrane current [41]. In frog taste cells, Avenet and Lindemann [44] found that permeability ratio varied considerably among cells, reflecting a scarce selectivity of the amiloride-sensitive channel, which conducts well also $\mathrm{K}^{+}$. In rodent fungiform taste cells, on the contrary, $\mathrm{ENaC}$ is more permeable to $\mathrm{Na}^{+}$than to $\mathrm{K}^{+}$(mouse: $\mathrm{P}_{\mathrm{Na}} / \mathrm{P}_{\mathrm{K}}=3.7$ [46]; rat: $\mathrm{P}_{\mathrm{Na}} / \mathrm{P}_{\mathrm{K}} \approx 4$ [56]). Thus, available data indicate that taste $\mathrm{ENaC}$ works essentially as sodium receptor inasmuch it produces large current carried by $\mathrm{Na}^{+}$in physiological conditions (that is, taste cells at negative resting potentials and in the presence of mucosal concentration of $\mathrm{Na}^{+}$of tens of $\mathrm{mM}$ ). In transporting epithelia, ENaC typically shows larger permeability to $\mathrm{Na}^{+}$compared to $\mathrm{K}^{+}$, with $\mathrm{P}_{\mathrm{Na}} / \mathrm{P}_{\mathrm{K}}>10$ [40] [75] [76]. However, amiloride-sensitive channels with $\mathrm{P}_{\mathrm{Na}} / \mathrm{P}_{\mathrm{K}}$ of 3 - 6 have been described too [40].

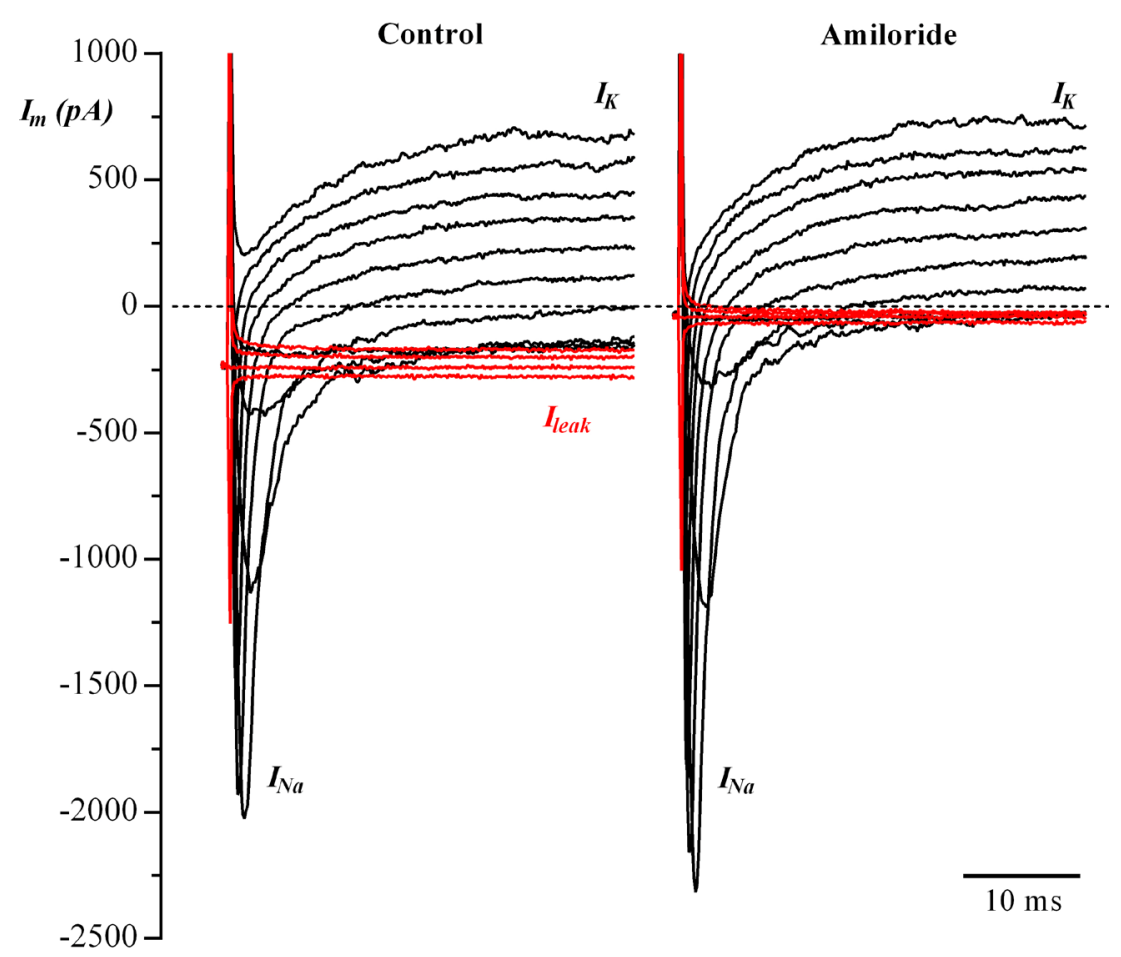

Figure 2. Whole-cell, voltage-clamp recordings from a taste cell of rat fungiform papilla. Cell was held at $-80 \mathrm{mV}$ and stepped in 10-mV increments from $-90 \mathrm{mV}$ to $40 \mathrm{mV}$. In standard extracellular solution (Control), taste cell exhibited a sustained, leakage current $\left(I_{\text {Leak }}\right)$ in addition to voltage-gated sodium currents $\left(I_{N a}\right)$ and potassium currents $\left(I_{K}\right)$. Leakage current was strongly reduced in the presence of $1 \mu \mathrm{M}$ amiloride (Amiloride). Note the magnitude increase of $I_{N a}$ during application of amiloride, likely reflecting an increase in the driving force for $\mathrm{Na}^{+}$due to a reduction of intracellular $\left[\mathrm{Na}^{+}\right]$as a consequence of ENaC block. $I_{m}$, whole-cell membrane current. Extracellular solution contained (in mM) $140 \mathrm{NaCl}, 5 \mathrm{KCl}, 2$ $\mathrm{CaCl}_{2}, 1 \mathrm{MgCl}_{2}$, 10 glucose, 10 sodium pyruvate, and 10 HEPES; $\mathrm{pH}$ 7.4. Pipette (intracellular) solution contained (in mM) $120 \mathrm{KCl}, 1 \mathrm{CaCl}_{2}, 2 \mathrm{MgCl}_{2}, 10$ HEPES, 11 EGTA, and $2 \mathrm{ATPNa}_{2}$, pH 7.2. 


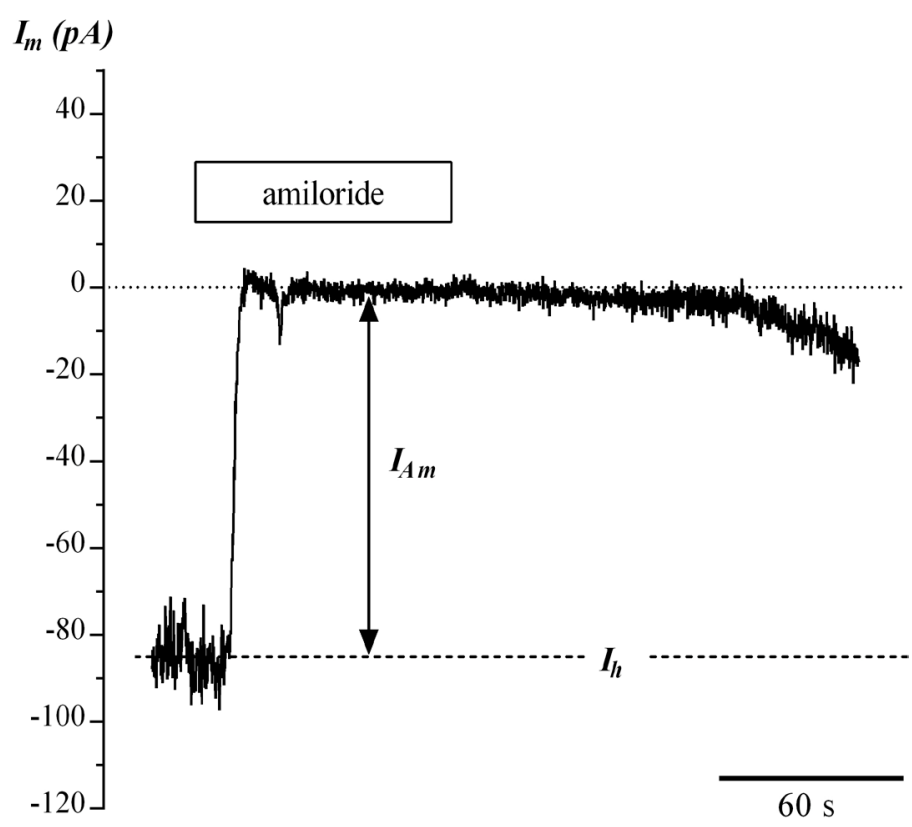

Figure 3. Response to amiloride elicited in a taste cell from rat fungiform papilla. Cell was held at $-80 \mathrm{mV}$ and amiloride (at a supramaximal dose of $50 \mu \mathrm{M}$ ) was bath applied. Application of amiloride (box over trace record) induced a decrease in the stationary inward current $\left(I_{h}\right.$, holding current). Note the reduction of the noise level in the current trace during amiloride application, consistent with the shut-down of ion channels. The effect of amiloride is due to blockage of ENaCs in the membrane of this cell. $I_{A m}$, amplitude of the response to amiloride; $I_{m}$, whole-cell membrane current. Whole-cell, voltageclamp configuration. Extracellular and pipette solutions as in Figure 2.

Taste $\mathrm{ENaC}$ is also permeable to other monovalent cations, such as $\mathrm{Li}^{+}$and $\mathrm{Cs}^{+}$[48] [58]. $\mathrm{Cs}^{+}$, often used as main cation in the patch pipette solution, is less permeable than $\mathrm{Na}^{+}$through ENaCs (e.g., [44] [58]). Figure 4(a) shows the response to amiloride in rat taste cells obtained by using a $\mathrm{KCl}$ (left) or $\mathrm{CsCl}$ (right) pipette solution. Note that the response amplitude is scarcely affected by the substitution of $\mathrm{K}^{+}$by $\mathrm{Cs}^{+}$(Figure 4(b)). In hamster fungiform taste cells, $\mathrm{ENaC}$ is also permeable to $\mathrm{H}^{+}$[45] suggesting its possible involvement in acid detection, at least in this rodent [77].

Amiloride sensitivity - It is well known that amiloride blocks not only ENaC but also other membrane transport/channel proteins depending on its concentration [8] [48] [76] [78]. As suggested by Lindemann [8], "if concentrations above $10 \mu \mathrm{M}$ are needed for half-maximal inhibition, effects of amiloride other than blockage of $\mathrm{Na}^{+}$channels need to be considered". The amiloride sensitivity of taste ENaC is obtained with the standard procedure of the dose-response curve. The amplitude of the response to amiloride (Figure $3, I_{A m}$ ) is measured by adding increasing concentrations of the drug into the bath solution. Data are then fitted to a single-binding isotherm [79], that is, Hill coefficient is set to 1 based on a 1:1 stoichiometry for the interaction amiloride/ENaC [76]: this equation yields the inhibition constant $\left(K_{i}\right)$ for amiloride. Native and cloned ENaCs display $K_{i}$ in the range of $0.1-1 \mu \mathrm{M} \mathrm{[40]} \mathrm{[75]} \mathrm{[76],} \mathrm{indicating} \mathrm{the} \mathrm{high} \mathrm{sensitivity} \mathrm{of} \mathrm{the} \mathrm{channel} \mathrm{to} \mathrm{amiloride.} \mathrm{Also} \mathrm{in} \mathrm{taste} \mathrm{cells,}$ amiloride acts as a potent channel blocker, with $K_{i}$ ranging from $\sim 0.01$ to $\sim 3 \mu \mathrm{M}$ in different species and preparations (see Table 1). These data confirm that taste ENaC strongly resembles the channel expressed abundantly by transporting epithelia. In taste cells, however, $\mathrm{ENaC}$ holds a receptor role rather than mediating $\mathrm{Na}^{+}$reabsorption: that is, these sensory cells exploit an epithelial channel to "capture" $\mathrm{Na}^{+}$dissolved in the saliva to produce with it electrical signaling. It is worth noting that determining $K_{i}$ is useful to distinguish $\mathrm{ENaC}$ from other sodium transporters, which display much larger $K_{i}$ [78] [80], in mediating the amiloride effect.

Sodium self-inhibition - In transporting epithelia, $\mathrm{Na}^{+}$transfer across cell lining shows saturation with increasing extracellular $\mathrm{Na}^{+}$concentrations [40]. Several mechanisms have been proposed to explain this 
(a)

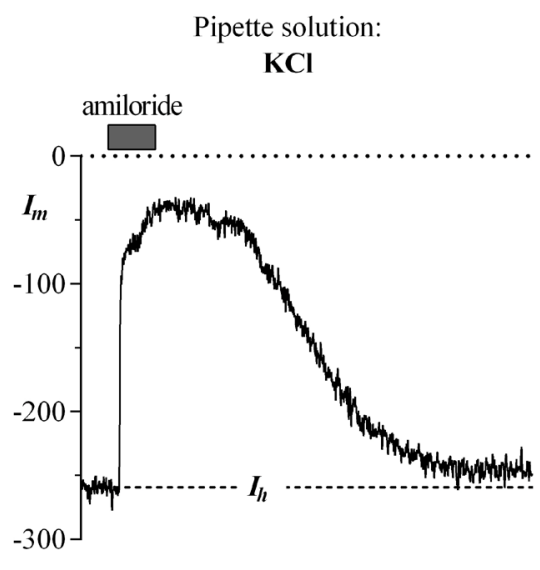

(b)

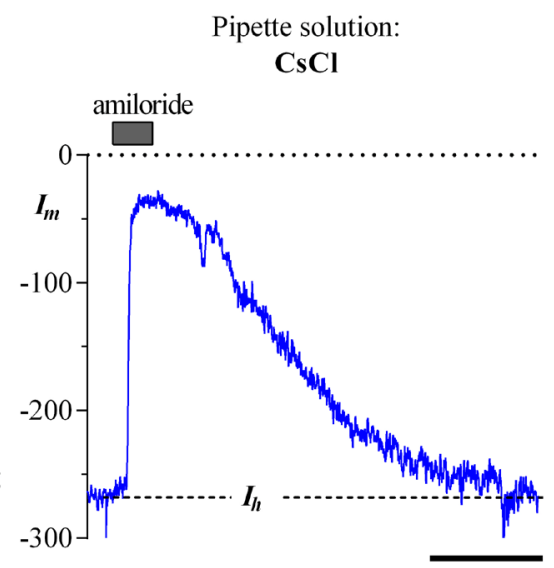

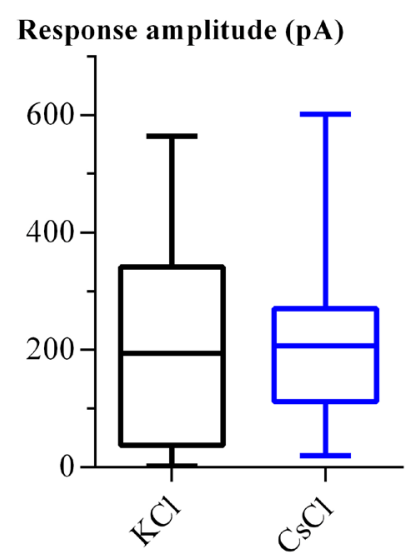

Pipette solution

Figure 4. Response to amiloride in rat taste cells obtained by using different (KCl- or CsCl-based) pipette solutions. (a), Sample response recorded from a taste cell with a standard $\mathrm{KCl}$ filling solution (left) and from another cell with CsCl substituting $\mathrm{KCl}$ (right). Cells were held at $-80 \mathrm{mV}$ and amiloride $(1 \mu \mathrm{M})$ was bath-applied (boxes over records). Horizontal scale bar: $100 \mathrm{sec} . I_{h}$, holding current (stationary inward current). $I_{m}$, whole-cell membrane current. (b), Comparison of the amplitude of the response to amiloride measured in 34 cells with $\mathrm{KCl}$ pipette solution and in 18 cells with CsCl pipette solution. Data are represented in the form of box and whiskers plots. Boxes show the middle half of the data (the 25th and 75th percentiles) and the horizontal line marks the median, whereas the "whiskers" extending from the top and the bottom of the boxes show the body of the data. Statistical analysis indicated that the two distributions were not significantly different (Mann Whitney test: $\mathrm{P}=0.5386$ ). Whole-cell, voltage-clamp configuration. Extracellular and pipette solutions as in Figure 2.

Table 1. Blocking effect of amiloride on taste ENaC expressed by the inhibition constant $\left(K_{i}\right)$.

\begin{tabular}{|c|c|c|c|}
\hline Species & Preparation & $K_{i}(\mu \mathrm{M})$ & Reference \\
\hline Frog (rod cells: receptor cells) & Isolated taste cells & 0.3 & [44] \\
\hline Frog (wing cells: glial-like cells) & “ & 3.3 & [49] \\
\hline Hamster (fungiform papilla) & Isolated taste buds & 0.2 & [45] \\
\hline Rat (fungiform papilla) & “ & 0.01 & [27] \\
\hline “ & “ & 0.2 & [52] \\
\hline “ & “ & 0.11 & [56] \\
\hline Rat (foliate papilla) & “ & 0.1 & [27] \\
\hline Mouse (fungiform papilla) & Single taste bud in semi-intact preparation & 0.2 & [58] \\
\hline
\end{tabular}

regulation of sodium permeability, such as a decrease in the elettrochemical gradient driving the influx of $\mathrm{Na}^{+}$as its intracellular concentration increases, an allosteric interaction of extracellular $\mathrm{Na}^{+}$with ENaC (sodium selfinhibition), or an indirect effect on channel activity induced by intracellular sodium or calcium [40]. Whatever the mechanism is, the biological significance of this regulation is to limit the sodium transport to avoid excessive intracellular build-up of an osmotically active particle: $\mathrm{Na}^{+}$content and volume of epithelial cells are therefore controlled. In a nice series of patch-clamp experiments, Gilbertson and Zhang [53] demonstrated that also in rat fungiform taste cells $\mathrm{Na}^{+}$influx through ENaCs is regulated by extracellular $\mathrm{Na}^{+}$. According to their findings, taste ENaCs are subjected to slowly (10 - $15 \mathrm{~s})$ developing self-inhibition. They proposed that this process could play a role in the sensory adaptation to salt stimuli. Indeed, the phasic/tonic spike responses to step increase in apical $\mathrm{Na}^{+}$concentration observed in single taste buds in the intact rat tongue [81] might be a consequence of self-inhibition.

It is worth noting that self-inhibition can be observed also in the response to amiloride. In frog taste cells, amiloride washing out produces a transient undershooting in the stationary current before relaxing to baseline level [44] [49]. This phenomenon has been observed also in rat taste cells [52]. $\mathrm{Na}^{+}$and amiloride binding sites 
are closely associated in the channel protein and, as a pore blocker, amiloride may interact with $\mathrm{Na}^{+}$[42] [76]: therefore, amiloride application removes $\mathrm{Na}^{+}$self-inhibition producing an increase in stationary inward current upon drug washing out.

If sodium self-inhibition depends on the extracellular concentration of $\mathrm{Na}^{+}$, one obvious question is then why in the presence of physiological saline with a sodium content of about $150 \mathrm{mM}$ we still can record conspicuous amiloride-sensitive sodium currents (Figure 4). A possible explanation provided by Gilbertson and Zhang [53] is that at high $\mathrm{Na}^{+}$concentrations the driving force for $\mathrm{Na}^{+}$entering the cell surmounts the self-inhibition effect. According to their data, self-inhibition seems to be more pronounced (and physiologically relevant for channels in the apical membrane bathed by saliva) with lower $\mathrm{Na}^{+}$concentrations.

Response variability -Even under well-controlled recording conditions (that is, with seal and series resistances comparable among patched cells [47]), the amplitude of the response to a given dose of amiloride is quite variable from cell to cell (Figure 4(b); see also [44]). A possible explanation for this variability is that, for some reasons, the enzymatic treatment used to isolate taste cells or taste buds affects ENaCs. However, amiloride is always added to the enzyme mixture and to all solutions during the dissociation procedure to protect the amiloride-sensitive $\mathrm{Na}^{+}$channels from enzymatic degradation [44] [45] [82]. Alternatively, amplitude variability of the response to amiloride could be related to taste cell growth. Maturation processes during turnover affect the expression of voltage-gated channels [83] and therefore taste cells appear as an electrophysiologically heterogeneous population of sensory cells (e.g. [84] [85]). Thus, it is reasonable to conceive that also functional expression of ENaCs may undergo changes during cell development, which would result in response to amiloride of varying amplitude. Also, the relative proportion of taste cells endowed with functional ENaCs and the amplitude of the response may depend on hormonal status of the animal [86]. Finally, the lack of response to amiloride observed in specific cell subsets [50] [55] may be interpreted on the basis of the functional specialization of taste cells (“receptor cells" vs. "pre-synaptic cells" [87] [88]).

\subsection{Excised Membrane Patches}

The analysis of single-channel activity of $\mathrm{ENaC}$ in taste cells has proved to be a difficult task, as demonstrated by the almost complete lack of relevant information in the literature. In frog taste cells, unit conductance $\left(\gamma_{E N a C}\right)$ is so tiny that it has been impossible to resolve single channel events in membrane patches, which are typically very noisy [48]. Fluctuation analysis [72] allowed to estimate a value $<2 \mathrm{pS}$ for $\gamma_{E N a C}$ [70]. Single-channel events have been recorded only once by Patrick Avenet [17] in preliminary experiments with rat taste cells, but his report was not followed by a full paper. In outside-out patches, he was able to resolve some channel events yielding a $\gamma_{E N a C}$ of about $5 \mathrm{pS}$, which is close to the value for the typical channel of transporting epithelia $(4-7 \mathrm{pS}$ [40] [75] [76]). No information is available on the single-channel open probability $\left(P_{O}\right)$. In outside-out patches from frog taste cells, ENaC maintains the same sensitivity to amiloride $\left(K_{i}: 0.2-0.3 \mu \mathrm{M}\right)$ and ion selectivity $\left(\mathrm{P}_{\mathrm{Na}} / \mathrm{P}_{\mathrm{K}}<1\right)$ evaluated in whole-cell configuration [44] [48].

One interesting aspect of the electrophysiology of taste $\mathrm{ENaC}$ is that patch excision produces an increase in amiloride-sensitive current amplitude, as though quiescent channels become active after membrane excision. This phenomenon has been clearly observed in frog taste cells, in which the amplitude of the response to amiloride was normalized to the membrane capacitance [8] [48] [49]. The biological basis of this channel activation upon membrane excision is not known. However, it has been speculated that some cytoplasmic factors might inhibit ENaCs when the channels are resident in the intact basolateral cell membrane; these factors would be lost when switching to outside-out patches, thereby producing channel activation. Recent findings suggest that filamin, a cytoplasmic protein that binds actin in the cytoskeleton, inhibits ENaC activity [89]. It is tempting to speculate that during patch excision, the cytoskeleton layer under the cell membrane gets disrupted and this may remove a stationary inhibitory effect exerted by intracellular protein filaments on ENaCs.

\subsection{ENaC Subunit Composition and Properties of the Response to Amiloride}

ENaC consists typically of three non-identical, but homologous subunits, $\alpha$-, $\beta$-, and $\gamma$-ENaC [90]. Expression cloning in Xenopus oocytes has revealed that the $\alpha$-subunit is sufficient to induce channel activity, whereas the $\beta$ - and $\gamma$-subunits allow maximal expression of sodium current [91]. It is assumed that functional channel contains all three subunit proteins [91]-[93]. The occurrence of $\mathrm{ENaC}$ subunits in taste cells has been studied with molecular biological techniques and immunocytochemistry, which have confirmed the occurrence of the $\alpha, \beta$, 
and $\gamma$ subunits in taste tissue [86] [94]-[98]. Interestingly, their expression pattern among rat taste papillae matches quite well the observation that functional channels mostly occur in the anterior part of the tongue (fungiform papillae) in this rodent [27]. The low abundance of $\gamma$ and/or $\beta$ subunits in the rat vallate taste cells seem to be responsible for the lack of functional channels when the animal is in sodium balance [86] [97]. In mouse fungiform papillae, $\alpha$-, $\beta$-, and $\gamma$-ENaC subunits are expressed only by amiloride-sensitive cells but not by amiloride-insensitive ones [62].

One interesting outcome of the studies on the biophysical and pharmacological properties of cloned and native ENaCs of transporting epithelia is that subunit composition as well as covalent modifications of the channel protein (such as, phosphorylation by protein kinase A) may affect strongly both the ion selectivity $\left(P_{N a} / P_{K}\right)$ and the sensitivity to amiloride $\left(K_{i}\right)$ [75] [76] [99]-[101]. Since the analysis of the response to amiloride provides information on $P_{N a} / P_{K}$ and $K_{i}$, then these parameters can be used to get indirect clues on the biochemical and molecular status of taste $\mathrm{ENaC}$ in different experimental conditions [27] [52] [56].

The occurrence of $\alpha$-, $\beta$-, and $\gamma$-ENaC subunits in human fungiform papillae has been confirmed by molecular analysis [102] [103]. In man, however, also a $\delta$ subunit has been detected [23]. It has been proposed that the $\delta$ subunit replaces the $\alpha$ one in $\mathrm{ENaC}$ protein, making the channel less sensitive to amiloride [23].

\subsection{Response to Amiloride: Theoretical Considerations}

As described above (see Section 4.3.), single-channel analysis of taste $\mathrm{ENaC}$ has proven to be very tough. Thus, the response to amiloride recorded in whole-cell configuration is the only electrophysiological tool available at the moment to understand the functioning of ENaCs in taste cell physiology. Accordingly, it might be useful to determine the factors affecting this response from a biophysical point of view.

The amplitude of the response to a given dose of amiloride ( $I_{A m}$; Figure 3 ) depends both on the magnitude of the current crossing all open ENaCs and on their sensitivity to amiloride. According to the equation for a single-binding isotherm (Hill coefficient $=1$ ) [79] for the blocking effect of amiloride, $I_{A m}$ can be expressed as follows:

$$
I_{A m}=\left[A m /\left(A m+K_{i}\right)\right] \cdot I_{E N a C}
$$

where $\mathrm{Am}$ is the amiloride dose, $K_{i}$ is the inhibition constant for the amiloride effect, and $I_{E N a C}$ is the membrane current due to all open ENaCs. In turn, $I_{E N a C}$ can be expressed by the following expression:

$$
I_{E N a C}=G_{E N a C} \cdot\left(V_{m}-E_{r e v}\right)
$$

where $G_{E N a C}$ is the membrane conductance due to all ENaCs; $V_{m}$ is the membrane potential set during patch-clamp experiments (for example, $-80 \mathrm{mV}$ ); $E_{\text {rev }}$ is the reversal potential of the response to amiloride, which depends on the ion selectivity. The membrane conductance due to all open ENaCs can be written as follows:

$$
G_{E N a C}=N_{E N a C} \cdot P_{O} \cdot \gamma_{E N a C}
$$

where $N_{E N a C}$ is the number of functional ENaCs; $P_{O}$ is the single-channel open probability (a single ENaC switches continuously between a closed state and an open state; $P_{O}$ is related to the time fraction spent by channels in the open state); $\gamma_{E N a C}$ is the conductance of a single ENaC. On the basis of these considerations, we can now re-write Equation (1) as follows:

$$
I_{A m}=\left[A m /\left(A m+K_{i}\right)\right] \cdot N_{E N a C} \cdot P_{O} \cdot \gamma_{E N a C} \cdot\left(V_{m}-E_{r e v}\right)
$$

Equation (4) describes the factors that can affect the amplitude of the response to a given dose of amiloride $(\mathrm{Am})$, and serves as theoretical basis to interpret data obtained in different experimental conditions (for example, comparison of the response to amiloride in taste cells from normal fed vs. sodium-restricted animals, and so on). If sensitivity to amiloride $\left(K_{i}\right)$ as well as the reversal potential of the amiloride response $\left(E_{r e v}\right)$ do not change, then we can simplify Equation (4) as follows:

$$
I_{A m} \propto\left(N_{E N a C} \cdot P_{O}\right) \cdot \gamma_{E N a C}
$$

That is, the response to a given dose of amiloride depends on the number of functional channels $\left(N_{E N a C}\right)$, the 
single-channel behaviour $\left(P_{O}\right)$ and conductance $\left(\gamma_{E N a C}\right)$ in the confronting experimental conditions. Of course, it is necessary to use an amiloride dose that assures specificity, such as $1 \mu \mathrm{M}$ [8]. I have put in parenthesis the number of functional channels times the open probability, often called channel activity [104]-[106], because several physiological regulations affecting $\mathrm{ENaC}$ in transporting epithelia target $N_{E N a C}$ and/or $P_{O}$ rather than $\gamma_{E N a C}[40][75][76][107]-[109]$.

\subsection{Localization of ENaC in Taste Cell Subsets}

Early histological studies established that there are at least three main subsets of taste bud cells, named as type I, type II, and type III cells, on the basis of the morphological features, such as the cytoplasm appearance, the presence/absence of specific intracellular organelles, and the occurrence of synaptic-like contacts with nerve endings [13] [14]. Structural differences suggested these cell subtypes likely possessed distinct functional properties, and indeed initial electrophysiological studies on Necturus taste cells supported this hypothesis [110]. With the advent of molecular techniques it has been possible to confirm further that taste receptors and downstream molecular pathways are not expressed by all taste cells but are segregated in specific cell subsets: for example, taste cells responding to sweet, bitter and umami stimuli belong to the type II category, whereas those sensitive to acids are of type III [15] [21] [111].

It is not yet clear which cell type houses the molecular machinery for detecting sodium ions [7]. According to recent data obtained from mice [25], ENaC is found in a subset of taste cells separated from those expressing the transduction pathway for sweet, bitter, and umami compounds. Another study suggests that functional ENaCs occur in type I cells from mouse fungiform taste buds [50]. This finding is surprising because type I cells are thought to be non-excitable, supporting-like cells [21] [111], whereas salt-detecting cells generate action potentials during stimulation with $\mathrm{NaCl}$ in fungiform taste buds, and their firing activity is suppressed by amiloride applied to the apical membrane [60] [62] [77] [81]. Electrophysiological studies on rat fungiform taste cells indicate that ENaC-expressing cells are endowed with large voltage-gated ion currents underlying action potential [55] [56], similar to those found in type II cells [50] [112]. Interestingly, in frog taste papillae the so-called “wing cells”, which are believed to play a glial-like role, are endowed with functional amiloride-sensitive sodium currents [49] (Table 1). Also, Lin et al. [86] found that "rENaC subunit immunoreactivity is present in virtually all the taste cells" in rat fungiform papillae, and deduced that "rENaC immunoreactivity must occur in at least some type I taste cells”.

One aspect of taste cell biology that may explain the conflicting results described above, is that taste cells undergo continuous turnover [13]. Maturation processes affect inevitably the functional expression of membrane proteins, including ion channels [83], which might appear with different time courses due to different longevity of taste cells subsets [113]. Thus, it is conceivable that responses to amiloride could be detected also in immature taste cells, which may then be erroneously assigned to a wrong cell subset. Consistent with this hypothesis, Dooling and Gilbertson [27] found amiloride-sensitive sodium currents both in taste cells endowed with voltage-gated $\mathrm{Na}^{+}$and $\mathrm{K}^{+}$currents (an electrophysiological feature of both mature type II and III cells [50] [112]) and in taste cells expressing only voltage-gated $\mathrm{K}^{+}$currents, that is, in cells resembling type I cells [50] [85] but also immature cells [50] [83] [85]. Kossel et al. [52] obtained similar results. As pointed out by Doolin and Gilbertson [27], one way to exclude developing cells from the analysis of taste cells expressing amiloride-sensitive sodium currents is to include in the database only those cells endowed with both large voltage-gated $\mathrm{Na}^{+}$and $\mathrm{K}^{+}$ currents (see also [85]). Indeed, in rat fungiform taste buds, some cells endowed with voltage-gated $\mathrm{K}^{+}$currents only do exhibit responses to amiloride [56]; however, their amplitude is significant smaller than those recorded in cells possessing large voltage-gated $\mathrm{Na}^{+}$and $\mathrm{K}^{+}$currents.

Alternatively, the salt signal to be relayed to nerve fibers may result from integration processes inside taste buds [6], which may involve different, mature cell subtypes [7]. Interestingly, this seems to be the case for the transduction mechanism for the AI component of the salt taste [114] [115].

\section{Amiloride-Insensitive Sodium Receptors}

It is well-established that salt taste response includes an amiloride-insensitive $(A I)$ component in addition to the amiloride-sensitive, ENaC-mediated one [10]. Several studies have attempted to identify the mechanism underlying the AI response [11] [23]. Early taste nerve recording investigations suggested the possible role of the transient receptor potential V1 (TRPV1) channel as sodium receptor [116]; however, behavioral tests using 
TRPV1 knockout animals questioned this possibility [117] [118]. Other studies further suggest a non-gustatory role of TRPV1 receptors in salt perception [119] [120]. In short, the molecular identity of the AI sodium receptor has not been established yet [23]. Recent calcium imaging experiments combined with molecular, nerve recording and behavioral assays in mice indicate that the AI salt pathway occurs in specific subpopulations of type II and type III cells that respond also to other taste stimuli [114] [115]. These findings raise the possibility that encoding of AI salt taste may require peripheral processing [6].

In patch-clamp recordings, AI currents can be identified by substituting extracellular $\mathrm{Na}^{+}$with a large, impermeant cation such as $N$-methyl-D-glucamine (NMDG): in these conditions, the stationary inward current recorded by holding the membrane at negative potentials is reduced [27] [45] [52]. Interestingly, only NMDGblockable $\mathrm{Na}^{+}$currents can be found in rat circumvallate taste cells [27] suggesting a possible specialization of taste papillae as to the salt detection mechanism, at least in this rodent. Unlike ENaC-mediated transduction, AI current is not affected by amiloride and does not exhibit sodium self-inhibition [53]. In mouse fungiform papillae, amiloride-insensitive taste cells do not express ENaC subunits [62]. It is worth noting that recent calcium imaging data suggest that a sodium-conducting ion channel sensitive to osmotic stress might be involved in the AI transduction pathway [115].

In conclusion, besides the early patch-clamp observations, no data are available on the electrophysiology of the AI sodium receptors in single taste cells. Clearly, new studies are highly wanted, especially considering the importance of the AI component for the salt taste in humans [10] [29]-[31].

\section{Taste Sodium Receptors: What's Next?}

Several years of electrophysiological investigations have produced a lot of information about the mechanisms underlying sodium detection in taste cells. In particular, the role of the epithelial sodium channel (ENaC) as sodium receptor is quite well established. Yet, our understanding of salt taste reception is far from being complete. Several pieces of the puzzle are still missing. For example, it is not yet clear which taste cell type (I, II, or III?) specifically expresses ENaC (see Section 4.6.). Also, the mechanism underlying the communication of salt-sensitive cell with nerve endings and/or adjacent taste cells is not known (see Figure 1). Taste cells responding to sweet, bitter or umami substances use the calcium homeostasis modulator 1 (CALHM1) channel to release the neurotransmitter, ATP [121]. There are indications that ATP [122]-[124] and CALHM1 [125] are likely involved also in signaling saltiness to nerve fibers, but direct confirmation on single taste cells is lacking. Finally, our comprehension of the molecular events underlying the amiloride-insensitive pathways is just at its beginning (see Section 5.).

\section{Acknowledgements}

I wish to acknowledge the expert technical assistance of Mr. Claudio Frigeri.

\section{References}

[1] Mattes, R.D. (1997) The Taste for Salt in Humans. American Journal of Clinical Nutrition, 65, 692S-697S.

[2] McCaughey, S.A. and Scott, T.R. (1998) The Taste of Sodium. Neuroscience \& Biobehavioral Reviews, 22, 663-676. http://dx.doi.org/10.1016/S0149-7634(97)00067-5

[3] Breslin, P.A. (2013) An Evolutionary Perspective on Food and Human Taste. Current Biology, 23, R409-R418. http://dx.doi.org/10.1016/j.cub.2013.04.010

[4] DeSimone, J.A., Beauchamp, G.K., Drewnowski, A. and Johnson, G.H. (2013) Sodium in the Food Supply: Challenges and Opportunities. Nutrition Reviews, 71, 52-59. http://dx.doi.org/10.1111/nure.12006

[5] Bigiani, A., Ghiaroni, V. and Fieni, F. (2003) Channels as Taste Receptors in Vertebrates. Progress in Biophysics \& Molecular Biology, 83, 193-225. http://dx.doi.org/10.1016/S0079-6107(03)00058-0

[6] Roper, S.D. (2013) Taste Buds as Peripheral Chemosensory Processors. Seminars in Cell \& Developmental Biology, 24, 71-79. http://dx.doi.org/10.1016/j.semcdb.2012.12.002

[7] Roper, S.D. (2015) The Taste of Table Salt. Pflügers Archiv, 467, 457-463. http://dx.doi.org/10.1007/s00424-014-1683-z

[8] Lindemann, B. (1996) Taste Reception. Physiological Reviews, 76, 718-766.

[9] Stewart, R.E., DeSimone, J.A. and Hill, D.L. (1997) New Perspectives in Gustatory Physiology: Transduction, Development, and Plasticity. American Journal of Physiology, 272, C1-C26. 
[10] Halpern, B.P. (1998) Amiloride and Vertebrate Gustatory Responses to NaCl. Neuroscience and Biobehavioral Reviews, 23, 5-47. http://dx.doi.org/10.1016/S0149-7634(97)00063-8

[11] DeSimone, J.A. and Lyall, V. (2006) Taste Receptors in the Gastrointestinal Tract III. Salty and Sour Taste: Sensing of Sodium and Protons by the Tongue. American Journal of Physiology: Gastrointestinal and Liver Physiology, 291, G1005-G1010. http://dx.doi.org/10.1152/ajpgi.00235.2006

[12] Yoshida, R., Yasumatsu, K., Shigemura, N. and Ninomiya, Y. (2006) Coding Channels for Taste Perception: Information Transmission from Taste Cells to Gustatory Nerve Fibers. Archives of Histology and Cytology, 69, $233-242$. http://dx.doi.org/10.1679/aohc.69.233

[13] Finger, T.E. and Simon, S.A. (2000) Cell Biology of Taste Epithelium. In: Finger, T.E., Silver, W.L. and Restrepo, D., Eds., The Neurobiology of Taste and Smell, 2nd Edition, Wiley-Liss, Inc., New York, 287-314.

[14] Witt, M., Reutter, K. and Miller Jr., I.J. (2003) Morphology of the Peripheral Taste System. In: Doty, R.L., Ed., Handbook of Olfaction and Gustation, 2nd Edition, Marcel Dekker, Inc., New York, 651-677.

[15] Liman, E.R., Zhang, Y.V. and Montell, C. (2014) Peripheral Coding of Taste. Neuron, 81, 984-1000. http://dx.doi.org/10.1016/j.neuron.2014.02.022

[16] Vandenbeuch, A. and Kinnamon, S.C. (2009) Why Do Taste Cells Generate Action Potentials? Journal of Biology, 8, 42. http://dx.doi.org/10.1186/jbiol138

[17] Avenet, P. (1992) Role of Amiloride-Sensitive Sodium Channels in Taste. In: Corey, D.P. and Roper, S.D., Eds., Sensory Transduction, the Rockefeller University Press, New York, 272-279.

[18] Lindemann, B. (2001) Receptors and Transduction in Taste. Nature, 413, 219-225. http://dx.doi.org/10.1038/35093032

[19] Gilbertson, T.A. and Boughter Jr., J.D. (2003) Taste Transduction: Appetizing Times in Gustation. Neuroreport, 14, 905-911.

[20] Chandrashekar, J., Hoon, M.A., Ryba, N.J. and Zuker, C.S. (2006) The Receptors and Cells for Mammalian Taste. Nature, 444, 288-294. http://dx.doi.org/10.1038/nature05401

[21] Chaudhari, N. and Roper, S.D. (2010) The Cell Biology of Taste. Journal of Cell Biology, 190, 285-296. http://dx.doi.org/10.1083/jcb.201003144

[22] Niki, M., Yoshida, R., Takai, S. and Ninomiya, Y. (2010) Gustatory Signaling in the Periphery: Detection, Transmission, and Modulation of Taste Information. Biological and Pharmaceutical Bulletin, 33, 1772-1777. http://dx.doi.org/10.1248/bpb.33.1772

[23] Bachmanov, A.A., Bosak, N.P., Lin, C., Matsumoto, I., Ohmoto, M., et al. (2014) Genetics of Taste Receptors. Current Pharmaceutical Design, 20, 2669-2683. http://dx.doi.org/10.2174/13816128113199990566

[24] Ye, W., Chang, R.B., Bushman, J.D., Tu, Y.H., Mulhall, E.M., et al. (2016) The K ${ }^{+}$Channel KIR2.1 Functions in Tandem with Proton Influx to Mediate Sour Taste Transduction. Proceedings of the National Academy of Sciences of the United States of America, 113, E229-E238. http://dx.doi.org/10.1073/pnas.1514282112

[25] Chandrashekar, J., Kuhn, C., Oka, Y., Yarmolinsky, D.A., Hummler, E., et al. (2010) The Cells and Peripheral Representation of Sodium Taste in Mice. Nature, 464, 297-301. http://dx.doi.org/10.1038/nature08783

[26] Lindemann, B. (1997) Sodium Taste. Current Opinion in Nephrology and Hypertension, 6, 425-429. http://dx.doi.org/10.1097/00041552-199709000-00003

[27] Doolin, R.E. and Gilbertson, T.A. (1996) Distribution and Characterization of Functional Amiloride-Sensitive Sodium Channels in Rat Tongue. Journal of General Physiology, 107, 545-554. http://dx.doi.org/10.1085/jgp.107.4.545

[28] Gilbertson, T.A. and Fontenot, D.T. (1998) Distribution of Amiloride-Sensitive Sodium Channels in the Oral Cavity of the Hamster. Chemical Senses, 23, 495-499. http://dx.doi.org/10.1093/chemse/23.5.495

[29] McCutcheon, N.B. (1992) Human Psychophysical Studies of Saltiness Suppression by Amiloride. Physiology \& Behavior, 51, 1069-1074. http://dx.doi.org/10.1016/0031-9384(92)90094-I

[30] Tennissen, A.M. (1992) Amiloride Reduces Intensity Responses of Human Fungiform Papillae. Physiology \& Behavior, 51, 1061-1068. http://dx.doi.org/10.1016/0031-9384(92)90093-H

[31] Feldman, G.M., Mogyorosi, A., Heck, G.L., DeSimone, J.A., Santos, C.R., et al. (2003) Salt-Evoked Lingual Surface Potential in Humans. Journal of Neurophysiology, 90, 2060-2064. http://dx.doi.org/10.1152/jn.00158.2003

[32] Heck, G.L., Mierson, S. and DeSimone, J.A. (1984) Salt Taste Transduction Occurs Through an Amiloride-Sensitive Sodium Transport Pathway. Science, 223, 403-405. http://dx.doi.org/10.1126/science.6691151

[33] Schiffman, S.S., Lockhead, E. and Maes, F.W. (1983) Amiloride Reduces the Taste Intensity of $\mathrm{Na}^{+}$and $\mathrm{Li}^{+} \mathrm{Salts}$ and Sweeteners. Proceedings of the National Academy of Sciences of the United States of America, 80, 6136-6140. http://dx.doi.org/10.1073/pnas.80.19.6136 
[34] Hamill, O.P., Marty, A., Neher, E., Sakmann, B. and Sigworth, F.J. (1981) Improved Patch-Clamp Techniques for High-Resolution Current Recording from Cells and Cell-Free Membrane Patches. Pflugers Archiv, 391, 85-100. http://dx.doi.org/10.1007/BF00656997

[35] Fatt, P. (1961) Intracellular microelectrodes. Methods in Medical Research, 9, 381-404.

[36] Roper, S. (1983) Regenerative Impulses in Taste Cells. Science, 220, 1311-1312. http://dx.doi.org/10.1126/science.6857254

[37] Avenet, P. and Lindemann, B. (1987) Patch-Clamp Study of Isolated Taste Receptor Cells of the Frog. Journal of Membrane Biology, 97, 223-240. http://dx.doi.org/10.1007/BF01869225

[38] Spielman, A.I., Mody, I., Brand, J.G., Whitney, G., MacDonald, J.F., et al. (1989) A Method for Isolating and PatchClamping Single Mammalian Taste Receptor Cells. Brain Research, 503, 326-329. http://dx.doi.org/10.1016/0006-8993(89)91684-3

[39] Béhé, P., DeSimone, J.A., Avenet, P. and Lindemann, B. (1990) Membrane Currents in Taste Cells of the Rat Fungiform Papilla. Evidence for Two Types of Ca Currents and Inhibition of K Currents by Saccharin. Journal of General Physiology, 96, 1061-1084. http://dx.doi.org/10.1085/jgp.96.5.1061

[40] Garty, H. and Palmer, L.G. (1997) Epithelial Sodium Channels: Function, Structure, and Regulation. Physiological Reviews, 77, 359-396.

[41] Hille, B. (2001) Ion Channels of Excitable Membranes. 3rd Edition, Sinauer Associates Inc., Sunderland.

[42] Kellenberger, S. and Schild, L. (2015) International Union of Basic and Clinical Pharmacology. XCI. Structure, Function, and Pharmacology of Acid-Sensing Ion Channels and the Epithelial $\mathrm{Na}^{+}$Channel. Pharmacological Reviews, 67, 1-35. http://dx.doi.org/10.1124/pr.114.009225

[43] Benos, D.J. (1982) Amiloride: A Molecular Probe of Sodium Transport in Tissues and Cells. American Journal of Physiology, 242, C131-C145.

[44] Avenet, P. and Lindemann, B. (1988) Amiloride-Lockable Sodium Currents in Isolated Taste Receptor Cells. Journal of Membrane Biology, 105, 245-255. http://dx.doi.org/10.1007/BF01871001

[45] Gilbertson, T.A., Roper, S.D. and Kinnamon, S.C. (1993) Proton Currents through Amiloride-Sensitive $\mathrm{Na}^{+}$Channels in Isolated Hamster Taste Cells: Enhancement by Vasopressin and cAMP. Neuron, 10, 931-942. http://dx.doi.org/10.1016/0896-6273(93)90208-9

[46] Miyamoto, T., Miyazaki, T., Okada, Y. and Sato, T. (1996) Whole-Cell Recording from Non-Dissociated Taste Cells in Mouse Taste Bud. Journal of Neuroscience Methods, 64, 245-252. http://dx.doi.org/10.1016/0165-0270(95)00138-7

[47] Marty, A. and Neher, E. (1995) Tight-Seal Whole-Cell Recording. In: Sakmann, B. and Neher, E., Eds., Single-Channel Recording, 2nd Edition, Plenum Press, New York, 31-52. http://dx.doi.org/10.1007/978-1-4419-1229-9_2

[48] Avenet, P. and Lindemann, B. (1989) Chemoreception of Salt Taste. The Blockage of Stationary Sodium Currents by Amiloride in Isolated Recpetor Cells and Excised Membrane Patches. In: Brand, J.G., Teeter, J.H., Cagan, R.H. and Kare, M.R., Eds., Chemical Senses: Molecular Aspects of Taste and Odor Reception, Marcel Dekker, New York, 171182.

[49] Bigiani, A. (2001) Amiloride-Sensitive Sodium Currents in Identified Taste Cells of the Frog. Neuroreport, 12, 1315-1321. http://dx.doi.org/10.1097/00001756-200105250-00006

[50] Vandenbeuch, A., Clapp, T.R. and Kinnamon, S.C. (2008) Amiloride-Sensitive Channels in Type I Fungiform Taste Cells in Mouse. BMC Neuroscience, 9, 1. http://dx.doi.org/10.1186/1471-2202-9-1

[51] Baquero, A.F. and Gilbertson, T.A. (2011) Insulin Activates Epithelial Sodium Channel (ENaC) Via Phosphoinositide 3-Kinase in Mammalian Taste Receptor Cells. American Journal of Physiology—Cell Physiology, 300, C860-C871. http://dx.doi.org/10.1152/ajpcell.00318.2010

[52] Kossel, A.H., McPheeters, M., Lin, W. and Kinnamon, S.C. (1997) Development of Membrane Properties in Taste Cells of Fungiform Papillae: Functional Evidence for Early Presence of Amiloride-Sensitive Sodium Channels. Journal of Neuroscience, 17, 9634-9641.

[53] Gilbertson, T.A. and Zhang, H. (1998) Self-Inhibition in Amiloride-Sensitive Sodium Channels in Taste Receptor Cells. Journal of General Physiology, 111, 667-677. http://dx.doi.org/10.1085/jgp.111.5.667

[54] Lin, W. and Kinnamon, S.C. (1999) Co-Localization of Epithelial Sodium Channels and Glutamate Receptors in Single Taste Cells. Biological Signals and Receptors, 8, 360-365. http://dx.doi.org/10.1159/000014609

[55] Bigiani, A. and Cuoghi, V. (2007) Localization of Amiloride-Sensitive Sodium Current and Voltage-Gated Calcium Currents in Rat Fungiform Taste Cells. Journal of Neurophysiology, 98, 2483-2487. http://dx.doi.org/10.1152/jn.00716.2007

[56] Bigiani, A. (2015) Amiloride-Sensitive Sodium Currents in Fungiform Taste Cells of Rats Chronically Exposed to Nicotine. Neuroscience, 284, 180-191. http://dx.doi.org/10.1016/j.neuroscience.2014.09.077 
[57] Miyamoto, T., Fujiyama, R., Okada, Y. and Sato, T. (1999) Strain Difference in Amiloride-Sensitivity of Salt-Induced Responses in Mouse Non-Dissociated Taste Cells. Neuroscience Letters, 17, 13-16. http://dx.doi.org/10.1016/S0304-3940(99)00828-9

[58] Miyamoto, T., Miyazaki, T., Fujiyama, R., Okada, Y. and Sato, T. (2001) Differential Transduction Mechanisms Underlying NaCl- and KCl-Induced Responses in Mouse Taste Cells. Chemical Senses, 26, 67-77. http://dx.doi.org/10.1093/chemse/26.1.67

[59] Furue, H. and Yoshii, K. (1997) In Situ Tight-Seal Recordings of Taste Substance-Elicited Action Currents and Voltage-Gated Ba Currents from Single Taste Bud Cells in the Peeled Epithelium of Mouse Tongue. Brain Research, 776, 133-139. http://dx.doi.org/10.1016/S0006-8993(97)00974-8

[60] Ohtubo, Y., Suemitsu, T., Shiobara, S., Matsumoto, T., Kumazawa, T., et al. (2001) Optical Recordings of Taste Responses from Fungiform Papillae of Mouse in Situ. Journal of Physiology, 530, 287-293. http://dx.doi.org/10.1111/j.1469-7793.2001.0287l.x

[61] Yoshida, R., Shigemura, N., Sanematsu, K., Yasumatsu, K., Ishizuka, S., et al. (2006) Taste Responsiveness of Fungiform Taste Cells with Action Potentials. Journal of Neurophysiology, 96, 3088-3095. http://dx.doi.org/10.1152/jn.00409.2006

[62] Yoshida, R., Horio, N., Murata, Y., Yasumatsu, K., Shigemura, N., et al. (2009). NaCl Responsive Taste Cells in the Mouse Fungiform Taste Buds. Neuroscience, 159, 795-803. http://dx.doi.org/10.1016/j.neuroscience.2008.12.052

[63] Gilbertson, T.A., Boughter Jr, J.D., Zhang, H. and Smith, D.V. (2001) Distribution of Gustatory Sensitivities in Rat Taste Cells: Whole-Cell Responses to Apical Chemical Stimulation. Journal of Neuroscience, 21, 4931-4941.

[64] Bigiani, A., Ewald, D.A. and Roper, S.D. (1995) The Lingual Slice Preparation, Isolated Taste Cells, and Dye Injections in Mudpuppy. In: Spielman, A.I. and Brand, J.G., Eds., Experimental Cell Biology of Taste and Olfaction Necturus Current Techniques and Protocols, CRC Press, Boca Raton, 65-71.

[65] Bigiani, A. (2002) Electrophysiology of Necturus Taste Cells. Progress in Neurobiology, 66, 123-159. http://dx.doi.org/10.1016/S0301-0082(02)00005-9

[66] Stevens, D.R., Seifert, R., Bufe, B., Müller, F., Kremmer, E., et al. (2001) Hyperpolarization-Activated Channels HCN1 and HCN4 Mediate Responses to Sour Stimuli. Nature, 413, 631-635. http://dx.doi.org/10.1038/35098087

[67] Gilbertson, T.A. (1995) Patch-Clamping of Taste Cells in Hamster and Rat. In: Spielman, A.I. and Brand, J.G., Eds., Experimental Cell Biology of Taste and Olfaction-Current Techniques and Protocols, CRC Press, Boca Raton, 317328.

[68] MacDonald, J.F., Mody, I., Salter, M. and Spielman, A.I. (1995) Patch-Clamping of Mouse Taste Receptor Cells. In: Spielman, A.I. and Brand, J.G., Eds., Experimental Cell Biology of Taste and Olfaction-Current Techniques and Protocols, CRC Press, Boca Raton, 329-332.

[69] Herness, M.S. (2002) Researching Isolated Taste Receptor Cells: Deciphering Transduction Cascades with Patch-Clamp and Calcium-Imaging Techniques. In: Simon, S.A. and Nicolelis, M.A.L., Eds., Methods in Chemosensory Research, CRC Press, Boca Raton, 169-206.

[70] Avenet, P. and Lindemann, B. (1990) Fluctuation Analysis of Amiloride-Blockable Currents in Membrane Patches Excised from Salt-Taste Receptor Cells. Journal of Basic and Clinical Physiology and Pharmacology, 1, 383-391. http://dx.doi.org/10.1515/JBCPP.1990.1.1-4.383

[71] Lindemann, B., Gilbertson, T.A. and Kinnamon, S.C. (1999) Amiloride-Sensitive Sodium Channels in Taste. In: Benos, D.J., Ed., Amiloride-Sensitive Sodium Channels_-Physiology and Functional Diversity, Academic Press, San Diego, 315-336. http://dx.doi.org/10.1016/S0070-2161(08)60966-1

[72] Lindemann, B. (1984) Fluctuation Analysis of Sodium Channels in Epithelia. Annual Review of Physiology, 46, 497515. http://dx.doi.org/10.1146/annurev.ph.46.030184.002433

[73] Bigiani, A. (2001) Mouse Taste Cells with Glialike Membrane Properties. Journal of Neurophysiology, 85, $1552-1560$.

[74] Lin, W., Burks, C.A., Hansen, D.R., Kinnamon, S.C. and Gilbertson, T.A. (2004) Taste Receptor Cells Express pHSensitive Leak K ${ }^{+}$Channels. Journal of Neurophysiology, 92, 2909-2919. http://dx.doi.org/10.1152/jn.01198.2003

[75] Benos, D.J., Awayda, M.S., Berdiev, B.K., Bradford, A.L., Fuller, C.M., et al. (1996) Diversity and Regulation of Amiloride-Sensitive $\mathrm{Na}^{+}$Channels. Kidney International, 49, 1632-1637. http://dx.doi.org/10.1038/ki.1996.237

[76] Kellenberger, S. and Schild, L. (2002) Epithelial Sodium Channel/Degenerin Family of Ion Channels: A Variety of Functions for a Shared Structure. Physiological Reviews, 82, 735-767. http://dx.doi.org/10.1152/physrev.00007.2002

[77] Gilbertson, T.A., Avenet, P., Kinnamon, S.C. and Roper, S.D. (1992) Proton Currents through Amiloride-Sensitive Na Channels in Hamster Taste Cells. Role in Acid Transduction. Journal of General Physiology, 100, 803-824.

http://dx.doi.org/10.1085/jgp.100.5.803 
[78] Kleyman, T.R. and Cragoe Jr., E.J. (1990) Cation Transport Probes: The Amiloride Series. Methods in Enzymology, 191, 739-755. http://dx.doi.org/10.1016/0076-6879(90)91045-8

[79] Rang, H.P. (1971) Drug Receptors and Their Function. Nature, 231, 91-96. http://dx.doi.org/10.1038/231091a0

[80] Kleyman, T.R. and Cragoe Jr., E.J. (1988) Amiloride and Its Analogs as Tools in the Study of Ion Transport. Journal of Membrane Biology, 105, 1-21. http://dx.doi.org/10.1007/BF01871102

[81] Avenet, P. and Lindemann, B. (1991) Noninvasive Recording of Receptor Cell Action Potentials and Sustained Currents from Single Taste Buds Maintained in the Tongue: The Response to Mucosal $\mathrm{NaCl}$ and Amiloride. Journal of Membrane Biology, 124, 33-41. http://dx.doi.org/10.1007/BF01871362

[82] Garty, H. and Edelman, I.S. (1983) Amiloride-Sensitive Trypsinization of Apical Sodium Channels: Analysis of Hormonal Regulation of Sodium Transport in Toad Bladder. Journal of General Physiology, 81, 785-803. http://dx.doi.org/10.1085/jgp.81.6.785

[83] Mackay-Sim, A., Delay, R.J., Roper, S.D. and Kinnamon, S.C. (1996) Development of Voltage-Dependent Currents in Taste Receptor Cells. Journal of Comparative Neurology, 365, 278-288. http://dx.doi.org/10.1002/(SICI)1096-9861(19960205)365:2<278::AID-CNE6>3.0.CO;2-2

[84] Ghiaroni, V., Fieni, F., Pietra, P. and Bigiani, A. (2003) Electrophysiological Heterogeneity in a Functional Subset of Mouse Taste Cells during Postnatal Development. Chemical Senses, 28, 827-833. http://dx.doi.org/10.1093/chemse/bjg076

[85] Medler, K.F., Margolskee, R.F. and Kinnamon, S.C. (2003) Electrophysiological Characterization of Voltage-Gated Currents in Defined Taste Cell Types of Mice. Journal of Neuroscience, 23, 2608-2617.

[86] Lin, W., Finger, T.E., Rossier, B.C. and Kinnamon, S.C. (1999) Epithelial $\mathrm{Na}^{+}$Channel Subunits in Rat Taste Cells: Localization and Regulation by Aldosterone. Journal of Comparative Neurology, 405, 406-420. http://dx.doi.org/10.1002/(SICI)1096-9861(19990315)405:3<406::AID-CNE10>3.0.CO;2-F

[87] Clapp, T.R., Medler, K.F., Damak, S., Margolskee, R.F. and Kinnamon, S.C. (2006) Mouse Taste Cells with G Protein-Coupled Taste Receptors Lack Voltage-Gated Calcium Channels and SNAP-25. BMC Biology, 4, 7. http://dx.doi.org/10.1186/1741-7007-4-7

[88] DeFazio, R.A., Dvoryanchikov, G., Maruyama, Y., Kim, J.W., Pereira, E., et al. (2006) Separate Populations of Receptor Cells and Presynaptic Cells in Mouse Taste Buds. Journal of Neuroscience, 26, 3971-3980. http://dx.doi.org/10.1523/JNEUROSCI.0515-06.2006

[89] Wang, Q., Dai, X.Q., Li, Q., Tuli, J., Liang, G., et al. (2013) Filamin Interacts with Epithelial Sodium Channel and Inhibits Its Channel Function. Journal of Biological Chemistry, 288, 264-273. http://dx.doi.org/10.1074/jbc.M112.396408

[90] Benos, D.J. and Stanton, B.A. (1999) Functional Domain within the Degenerin/Epithelial Sodium Channel (Deg/ENaC) Superfamily of Ion Channels. Journal of Physiology, 520, 631-644. http://dx.doi.org/10.1111/j.1469-7793.1999.00631.x

[91] Canessa, C.M., Schild, L., Buell, G., Thorens, B., Gautschi, I., et al. (1994) Amiloride-Sensitive Epithelial Na ${ }^{+}$Channel Is Made of Three Homologous Subunits. Nature, 367, 463-467. http://dx.doi.org/10.1038/367463a0

[92] Firsov, D., Gautschi, I., Merillat, A.-M., Rossier, B.C. and Schild, L. (1998) The Heterotetrameric Architecture of the Epithelial Sodium Channel (ENaC). EMBO Journal, 17, 344-352. http://dx.doi.org/10.1093/emboj/17.2.344

[93] Kosari, F., Sheng, S., Li, J., Mak, D.-O.D., Foskett, J.K., et al. (1998) Subunit Stoichiometry of the Epithelial Sodium Channel. Journal of Biological Chemistry, 273, 13469-13474. http://dx.doi.org/10.1074/jbc.273.22.13469

[94] Simon, S.A., Holland, V.F., Benos, D.J. and Zampighi, G.A. (1993) Transcellular and Paracellular Pathways in Lingual Epithelia and Their Influence in Taste Transduction. Microscopy Research and Technique, 15, 196-208. http://dx.doi.org/10.1002/jemt.1070260303

[95] Li, X.J., Blackshaw, S. and Snyder, S.H. (1994) Expression and Localization of Amiloride-Sensitive Sodium Channel Indicate a Role for Non-Taste Cells in Taste Perception. Proceedings of the National Academy of Sciences of the United States of America, 91, 1814-1818. http://dx.doi.org/10.1073/pnas.91.5.1814

[96] Lindemann, B., Barbry, P., Kretz, O. and Bock, R. (1998) Occurrence of ENaC Subunit mRNA and Immunocytochemistry of the Channel Subunits in Taste Buds of the Rat Vallate Papilla. Annals of the New York Academy of Sciences, 855, 116-127. http://dx.doi.org/10.1111/j.1749-6632.1998.tb10553.x

[97] Kretz, O., Barbry, P., Bock, R. and Lindemann, B. (1999) Differential Expression of RNA and Protein of the Three Pore-Forming Subunits of the Amiloride-Sensitive Epithelial Sodium Channel in Taste Buds of the Rat. Journal of Histochemistry and Cytochemistry, 47, 51-64. http://dx.doi.org/10.1177/002215549904700106

[98] Shigemura, N., Islam, A.A., Sadamitsu, C., Yoshida, R., Yasumatsu, K., et al. (2005) Expression of Amiloride-Sen- sitive Epithelial Sodium Channels in Mouse Taste Cells after Chorda Tympani Nerve Crush. Chemical Senses, 30, 531538. http://dx.doi.org/10.1093/chemse/bji046 
[99] Ismailov, I.I., Berdiev, B.K. and Benos, D.J. (1995) Biochemical Status of Renal Epithelial Na ${ }^{+}$Channels Determines Apparent Channel Conductance, Ion Selectivity, and Amiloride Sensitivity. Biophysical Journal, 69, 1789-1800. http://dx.doi.org/10.1016/S0006-3495(95)80049-4

[100] McNicholas, C.M. and Canessa, C.M. (1997) Diversity of Channels Generated by Different Combinations of Epithelial Sodium Channel Subunits. Journal of General Physiology, 109, 681-692. http://dx.doi.org/10.1085/jgp.109.6.681

[101] Benos, D.J., Fuller, C.M., Shlyonsky, V.G., Berdiev, B.K. and Ismailov, I.I. (1997) Amiloride-Sensitive $\mathrm{Na}^{+}$Channels: Insights and Outlooks. News in Physiological Sciences, 12, 55-61.

[102] Rossier, O., Cao, J., Huque, T., Spielman, A.I., Feldman, R.S., et al. (2004) Analysis of a Human Fungiform Papillae cDNA Library and Identification of Taste-Related Genes. Chemical Senses, 29, 13-23. http://dx.doi.org/10.1093/chemse/bjh002

[103] Stähler, F., Riedel, K., Demgensky, S., Neumann, K., Dunkel, A., et al. (2008) A Role of the Epithelial Sodium Channel in Human Salt Taste Transduction? Chemosensory Perception, 1, 78-90. http://dx.doi.org/10.1007/s12078-008-9006-4

[104] Marunaka, Y. and Eaton D.C. (1991) Effects of Vasopressin and cAMP on Single Amiloride-Blockable Na Channels. American Journal of Physiology, 260, C1071-C1084.

[105] Kemendy, A.E., Kleyman, T.R. and Eaton, D.C. (1992) Aldosterone Alters the Open Probability of Amiloride-Blockable Sodium Channels in A6 epithelia. American Journal of Physiology, 263, C825-C837.

[106] Ling, B.N., Kokko, K.E. and Eaton, D.C. (1992) Inhibition of Apical Na ${ }^{+}$Channels in Rabbit Cortical Collecting Tubules by Basolateral Prostaglandin $E_{2}$ Is Modulated by Protein Kinase C. Journal of Clinical Investigation, 90, 13281334. http://dx.doi.org/10.1172/JCI115998

[107] Rossier, B.C. (2002) Hormonal Regulation of the Epithelial Sodium Channel ENaC: N or P $P_{O}$ Journal of General Physiology, 120, 67-70. http://dx.doi.org/10.1085/jgp.20028638

[108] Butterworth, M.B. (2010) Regulation of the Epithelial Sodium Channel (ENaC) by Membrane Trafficking. Biochimica et Biophysica Acta, 1802, 1166-1177. http://dx.doi.org/10.1016/j.bbadis.2010.03.010

[109] Marunaka, Y. (2014) Characteristics and Pharmacological Regulation of Epithelial $\mathrm{Na}^{+}$Channel (ENaC) and Epithelial $\mathrm{Na}^{+}$Transport. Journal of Pharmacological Sciences, 126, 21-36. http://dx.doi.org/10.1254/jphs.14R01SR

[110] Bigiani, A., Kim, D.J. and Roper, S.D. (1996) Membrane Properties and Cell Ultrastructure of Taste Receptor Cells in Necturus Lingual Slices. Journal of Neurophysiology, 75, 1944-1956.

[111] Bigiani, A. and Prandi, S. (2011) Functional Diversity of Taste Cells. A review. Flavour and Fragrance Journal, 26, 214-217. http://dx.doi.org/10.1002/ffj.2065

[112] Kimura, K., Ohtubo, Y., Tateno, K., Takeuchi, K., Kumazawa, T., et al. (2014) Cell-Type-Dependent Action Potentials and Voltage-Gated Currents in Mouse Fungiform Taste Buds. European Journal of Neuroscience, 39, $24-34$. http://dx.doi.org/10.1111/ejn.12388

[113] Perea-Martinez, I., Nagai, T. and Chaudhari, N. (2013) Functional Cell Types in Taste Buds Have Distinct Longevities. PLOS ONE, 8, e53399. http://dx.doi.org/10.1371/journal.pone.0053399

[114] Oka, Y., Butnaru, M., von Buchholtz, L., Ryba, N.J. and Zuker, C.S. (2013) High Salt Recruits Aversive Taste Pathways. Nature, 494, 472-475. http://dx.doi.org/10.1038/nature11905

[115] Lewandowski, B.C., Sukumaran, S.K., Margolskee, R.F. and Bachmanov, A.A. (2016) Amiloride-Insensitive Salt Taste Is Mediated by Two Populations of Type III Taste Cells with Distinct Transduction Mechanisms. Journal of Neuroscience, 36, 1942-1953. http://dx.doi.org/10.1523/JNEUROSCI.2947-15.2016

[116] Lyall, V., Heck, G.L., Vinnikova, A.K., Ghosh, S., Phan, T.H., et al. (2004) The Mammalian Amiloride-Insensitive Non-Specific Salt Taste Receptor is a Vanilloid Receptor-1 Variant. Journal of Physiology, 558, 147-159. http://dx.doi.org/10.1113/jphysiol.2004.065656

[117] Ruiz, C., Gutknecht, S., Delay, E. and Kinnamon, S. (2006) Detection of NaCl and KCl in TRPV1 Knockout Mice. Chemical Senses, 31, 813-820. http://dx.doi.org/10.1093/chemse/bjl024

[118] Treesukosol, Y., Lyall, V., Heck, G.L., DeSimone, J.A. and Spector, A.C. (2007) A Psychophysical and Electrophysiological Analysis of Salt Taste in Trpv1 Null Mice. American Journal of Physiology - Regulatory, Integrative and Comparative Physiology, 292, R1799-R1809. http://dx.doi.org/10.1152/ajpregu.00587.2006

[119] Breza, J.M. and Contreras, R.J. (2012) Anion Size Modulates Salt Taste in Rats. Journal of Neurophysiology, 107, 1632-1648. http://dx.doi.org/10.1152/jn.00621.2011

[120] Smith, K.R., Treesukosol, Y., Paedae, A.B., Contreras, R.J. and Spector, A.C. (2012) Contribution of the TRPV1 Channel to Salt Taste Quality in Mice as Assessed by Conditioned Taste Aversion Generalization and Chorda Tympani Nerve Responses. American Journal of Physiology-Regulatory, Integrative and Comparative Physiology, 303, R1195-R1205. http://dx.doi.org/10.1152/ajpregu.00154.2012 
[121] Taruno, A., Vingtdeux, V., Ohmoto, M., Ma, Z., Dvoryanchikov, G., et al. (2013) CALHM1 Ion Channel Mediates Purinergic Neurotransmission of Sweet, Bitter and Umami Tastes. Nature, 495, 223-226. http://dx.doi.org/10.1038/nature11906

[122] Finger, T.E., Danilova, V., Barrows, J., Bartel, D.L., Vigers, A.J., et al. (2005) ATP Signaling Is Crucial for Communication from Taste Buds to Gustatory Nerves. Science, 310, 1495-1499. http://dx.doi.org/10.1126/science.1118435

[123] Eddy, M.C., Eschle, B.K., Barrows, J., Hallock, R.M., Finger, T.E. et al. (2009) Double P2X2/P2X3 Purinergic Receptor Knockout Mice Do Not Taste $\mathrm{NaCl}$ or The Artificial Sweetener SC45647. Chemical Senses, 34, 789-797. http://dx.doi.org/10.1093/chemse/bjp068

[124] Vandenbeuch, A., Larson, E.D., Anderson, C.B., Smith, S.A., Ford, A.P., et al. (2015) Postsynaptic P2X3-Containing Receptors in Gustatory Nerve Fibres Mediate Responses to All Taste Qualities in Mice. Journal of Physiology, 593, 1113-1125. http://dx.doi.org/10.1113/jphysiol.2014.281014

[125] Tordoff, M.G., Ellis, H.T., Aleman, T.R., Downing, A., Marambaud, P., et al. (2014) Salty Taste Deficits in CALHM1 Knockout Mice. Chemical Senses, 39, 515-528. http://dx.doi.org/10.1093/chemse/bju020

\section{Submit or recommend next manuscript to SCIRP and we will provide best service for you:}

Accepting pre-submission inquiries through Email, Facebook, Linkedin, Twitter, etc A wide selection of journals (inclusive of 9 subjects, more than 200 journals)

Providing a 24-hour high-quality service

User-friendly online submission system

Fair and swift peer-review system

Efficient typesetting and proofreading procedure

Display of the result of downloads and visits, as well as the number of cited articles

Maximum dissemination of your research work

Submit your manuscript at: http://papersubmission.scirp.org/ 